\title{
Dramaturgi Profesi Wartawan dalam Realita Kehidupan
}

\author{
https://doi.org/10.25008/parahita.v1i2.45
}

\author{
Infra Wahdaniah ${ }^{1^{*}}$, Prudensius Maring ${ }^{2}$ \\ ${ }^{1,2}$ Universitas Budi Luhur \\ Jl. Raya Ciledug Petukangan Utara, Kebayoran Lama Jakarta 12260 - Indonesia \\ *Korespondensi: infrawahdaniah@gmail.com
}

\begin{abstract}
Abstrak - Penelitian ini untuk mengetahui kehidupan profesi wartawan yang selama ini terlihat sebagai agen perubahan, penuh idealisme dalam menghadapi perubahan ke arah yang tidak lebih dari sekedar drama. Metode yang digunakan adalah kualitatif deskriptif dengan studi dramaturgi. Teknik pengumpulan data menggunakan snowball sampling, observasi, wawancara, dokumentasi. Analisis data dilakukan dengan teknik interaktif. Hasil penelitian ini menunjukkan bahwa wartawan sering berada di panggung depan (front stage) yang berkilau sehingga kalau dia tidak bisa kembali ke panggung belakang (back stage), maka akan terus bermain peran. Semua diperankan sebagai sosok wartawan yang serba tahu dan merasa paling penting. Ada juga yang bukan panggung depan dan panggung belakang tetapi menjadi saksi dari pertunjukkan yang berlangsung: yaitu daerah luar (residual).
\end{abstract}

Kata Kunci: Dramaturgi, wartawan, idealisme, perubahan

\begin{abstract}
This research is to find out the professional life of journalists who have been seen as agents of change, full of idealism, facing changes in the direction of nothing more than drama. The method used is descriptive qualitative studies of dramaturgy and data collection techniques using snowball sampling, observation, interviews, documentation. Data analysis was performed using interactive techniques. The results of this study indicate that journalists are often on the sparkling front stage so that if he cannot return to the back stage, he will continue to play a role. All are played as journalists who know everything and feel the most important. There are also those who are not the front stage and the back stage but are witnesses of the performance, which is the outer area (residual).
\end{abstract}

Keywords: Dramaturgy, journalist, idealism, change

\section{PENDAHULUAN}

Perubahan sosial masyarakat selalu terjadi setiap saat, sejalan dengan perkembangan jaman dan teknologi. Perubahan sosial juga mempengaruhi pergeseran budaya termasuk pergeseran budaya pers. Awal tahun 90-an, profesi wartawan masih termasuk profesi yang diminati. Padahal saat itu kebebasan pers yang menjadi acuan profesi ini berada dalam tekanan penguasa Orde Baru: ada sensor, intervensi penguasa bahkan ancaman pembredelan media.

Setahun sebelum reformasi 1998, jumlah media cetak belum banyak dibandingkan setahun pasca reformasi. Tahun 1997 jumlah Surat Izin Usaha Penerbitan Pers (SIUPP) sebanyak 289. Pada 1999 jumlah media mencapai 1.687 (Batubara, 2007). Saat ini ada 47.000 media dengan 14.000 orang memiliki sertifikasi kompetensi sebagai wartawan. Media yang terverifikasi Dewan Pers hanya sekitar 3000. Media-media yang belum terverifikasi juga mempekerjakan wartawan yang sebagian besar belum memiliki kompetensi sebagai reporter (Yosep AP, Mediaindonesia.com, 2019).

Wartawan Indonesia lahir dari semangat perjuangan di jaman revolusi untuk mewujudkan kemerdekaan. Sejumlah media lahir di tengah-tengah pergolakan. Para pekerja media masih menikmati kebanggaan karena menjadi bagian dari perjuangan. Masyarakat menaruh hormat dan menghargai profesi wartawan. Setidaknya itu dirasakan hingga awal tahun 90-an. Kehadiran wartawan ditunggu untuk sebuah acara. Kesannya 
mereka jadi sosok penting pada berbagai event.

Hal itu disebabkan kebutuhan transformasi sosial kala itu. Faktanya, dari beberapa kasus kecil yang diberitakan media cetak, sebuah pabrik gula jawa yang limbahnya mengganggu masyarakat bisa langsung ditutup. Padahal sebelumnya masyarakat sekitar pabrik melakukan demo sebagai protes agar pabrik tersebut ditutup, tapi tidak berhasil. Contoh lainnya adalah orang hilang bisa ditemukan setelah fotonya dimuat oleh wartawan di medianya. Bahkan wartawan seringkali menjadi tempat bertanya tentang banyak hal. Tidak hanya urusan kampung kumuh, sampah busuk, tetapi juga hal-hal remeh temeh yang bisa diselesaikan wartawan melalui medianya. Wartawan juga menjadi solusi dalam masalah nasional. Pernah juga ada seorang jenderal menunggu kepastian 'nasibnya' untuk mendapatkan penempatan. Melalui pertanyaan wartawan, dalam waktu 24 jam, jenderal tersebut langsung memperoleh jawaban atas masalahnya.

Melalui satu teks yang dihasilkan dari liputan wartawan, perubahan sosial dapat terjadi. Di dalam masyarakat telah tumbuh kesadaran kolektif atas perlunya kehadiran wartawan untuk menyampaikan berita yang perlu disebarkan. Masyarakat memandang wartawan bisa dipercaya hingga muncul anggapan: saat ada anak-anak atau nenek-nenek hilang, warga bukan melaporkannya ke kantor polisi melainkan mendatangi kantor redaksi media untuk bertemu wartawan. Bisa jadi inilah wujud tanggung jawab pers, sebagai pembawa informasi kepada masyarakat, sekaligus alarm bagi penguasa dan pengusaha.

Setelah reformasi 1998, profesi yang semula terhormat serta berwatak transformatif cenderung mengalami pergeseran nilai. Pemicunya adalah munculnya ribuan media baru berstatus abal-abal (Pangerapan, Kompas.com, 2017). Di masyarakat terbangun istilah minor terhadap profesi wartawan. Tidak ada lagi penghargaan. Hampir tiap hari media baru berguguran tetapi para wartawannya tidak gugur. Mereka merasa tetap menjadi wartawan, dekat dengan pejabat, punya akses, dan keluar masuk hotel.

Tapi itulah kenyataannya. Wartawan seperti rombongan pemain sirkus yang serba bisa. Mereka adalah para pemain sandiwara yang menurut teori dramaturgi Irving Gofman dibedakan oleh dua dunia. Mereka harus tahu kapan saatnya berada di panggung depan (front stage) dan kapan di belakang panggung (back stage). Wartawan menjadi pemain yang serba tahu, serba bisa tentang banyak hal. Wartawan akrab dengan selebritis bahkan tahu banyak tentang kehidupan mereka. Wartawan tahu tentang strategi politik aktual; wartawan serba tahu tentang berbagai kondisi dan pergerakan ekonomi. Wartawan bisa makan bersama menteri, pejabat tinggi bahkan presiden pada saat-saat tertentu.

Wartawan menulis informasi politik, hukum, ekonomi, budaya, presiden, menteri, gubernur, camat, kepala desa hingga gelandangan. Wartawan juga menulis tentang demo buruh karena gajinya tidak sesuai upah minimun propinsi (UMP). Tapi pada saat dia kembali ke panggung belakang, wartawan kembali ke aslinya: naik kendaraan umum, motor tua, harus membagi-bagi pendapatan antara kebutuhan rumah dan sekolah anak. Padahal dia baru saja menulis berita tentang demo buruh yang gajinya lebih rendah dari UMP.

Selain menyebut teori dramaturgi, Gofman juga mengatakan tentang individu sebagai hasil interaksi. Bahwa diri bukanlah sebagai aktor namun sebagai produk interaksi dramatis antara aktor dan audien. Diri adalah pengaruh dari suasana yang ditampilkan. Seorang individu menurut Gofman, umumnya mencoba untuk menunjukkan gambaran idealis yang terbaik mengenai dirinya sendiri di depan umum. Mereka merasa harus menyembunyikan apa yang diperbuat sehingga mampu mengelola kesan yang didambakan nilai dan norma masyarakat lingkunganya.

Gofman menggali perilaku interaksi yang terjadi sehari-hari yaitu menampilkan diri masing-masing dalam cara yang sama dengan cara seorang aktor menampilkan karakter orang lain di sebuah pertunjukkan drama. Pertunjukkan yang terjadi di masyarakat untuk 
memberi kesan yang baik guna mencapai tujuan. Tujuannya adalah penerimaan penonton terhadap manipulasi. Jika aktor berhasil, penonton akan melihat aktor sesuai dengan sudut yang dibawakan aktor, dan semakin mudah bagi aktor membawa penonton mencapai tujuan pertunjukan. Maka menjadi benar apa yang dikemukakan Naomy Chomsky bahwa berita di media hanyalah sebuah rekonstruksi tertulis atas suatu realitas yang ada di masyarakat. Semua tergantung siapa orang di balik berita itu (Chomsky, 2018).

Dari latar belakang tersebut, maka penelitian ini merumuskan permasalahan sebagai berikut: "bagaimana kehidupan profesi wartawan yang selama ini terlihat sebagai agen perubahan, penuh idealisme, menghadapi perubahan ke arah yang tidak lebih dari sekedar drama dalam kehidupan mereka sehari-harinya".

\section{METODE PENELITIAN}

Penelitian ini menggunakan pendekatan kualitatif, dengan studi dramaturgi yang mendeskripsikan kondisi empiris hasil temuan di lapangan, terkait dengan perubahan dimensi sosial kehidupan pers dari idealisme menjadi pragmatis seperti praktek drama di panggung pertunjukkan. Menurut Norman K Denzim Yvonna S Lincoln (2009), secara abstrak data kualitatif mengacu pada esensi manusia, objek dan situasi.

Dalam penelitian ini digunakan sumber data dari beberapa informan sebagai pelaku. Ada informan utama yang selanjutnya merekomendasikan perolehan data kepada informan kedua dan ketiga. Peneliti tidak mengenal secara baik informan secara keseluruhan sehingga berlaku bagai orang awam yang datang ke lokasi dan berkenalan. Pelibatan beberapa informan bertujuan agar data yang diperoleh bisa saling melengkapi dan mendalam.

Pengumpulan data dalam penelitian ini menggunakan teknik snowball sampling. Penelitian dilakukan secara langsung di satu gedung lembaga tinggi negara sebagai epicentrum kegiatan politik di tanah air.

Teknik pengumpulan data melalui observasi, wawancara mendalam dan dokumentasi. Penelitian juga menerapkan pendekatan trianggulasi data (sumber) dengan menggunakan berbagai sumber untuk mengumpulkan data yang sama sebagai validasi. Data trianggulasi digunakan sebagai penguat data yang disebutkan informan, berupa observasi maupun wawancara sejawat informan ataupun pelayan/staf yang memahami seluk beluk kehidupan wartawan. Teknik analisis data menggunakan model interaktif dari pengumpulan dan reduksi data, penyajian hingga kesimpulan.

\section{HASIL DAN PEMBAHASAN}

Wartawan menurut Undang-Undang Nomor 40 Tahun 1999 tentang Pers adalah orang yang secara teratur melaksanakan kegiatan jurnalistik. Tentu saja orang yang melakukan kegiatan jurnalistik tetapi tidak teratur, tidak bisa disebut sebagai wartawan. Selain itu wartawan juga harus bekerja di perusahaan pers yang berbadan hukum Indonesia, memiliki alamat kantor, dan pengurus perusahaan sebagaimana diatur dalam Undang-Undang Pers.

Dalam penelitian ini yang dikaji adalah wartawan sesuai dengan ketentuan UndangUndang Pers, bukan orang yang melakukan kegiatan jurnalistik tetapi tidak sesuai dengan Undang-Undang Pers. Misalnya saja pegiat media sosial, meskipun mereka melakukan kegiatan jurnalistik, mereka tidak bekerja di perusahaan pers; mereka tidak memiliki badan hukum pers, dan yang pasti mereka belum tentu melakukan kegiatan jurnalistik secara rutin dan konsisten seperti media massa harian, mingguan atau bulanan.

Mereka yang melakukan kerja jurnalistik setiap hari, mempunyai media tetapi tidak memiliki kantor dan medianya tidak berbadan hukum, termasuk dalam kajian ini. Cara kerja seperti itu merupakan sebuah pelanggaran yang dilakukan oleh orang-orang pers 
yang sebenarnya tahu aturan. Meski begitu, mereka diperlakukan sama dengan wartawan yang bekerja di perusahaan pers.

Hal ini menjadi penyebab meningkatnya media online hingga lebih dari 43 ribu. Ketua Dewan Pers periode 2016-2019 Yosef Adi Prasetyo dan juga Dirjen Aptika Kemenkominfo, Samuel Abrijani Pangerapan menyebut ada lebih dari 43 ribu media online sebagian merupakan media abal-abal. Media disebut abal-abal, karena produk dan wartawannya tidak jelas.

Ada wartawan yang sebenarnya bekerja di perusahaan pers yang berbadan hukum dan memiliki kantor maupun pengurus media, tetapi karena kondisi keuangan medianya tidak memadai, maka wartawannya tidak digaji. Wartawannya hanya mengandalkan pendapatan dari pemberian amplop kegiatan. Tidak jarang mereka ditugaskan perusahaan untuk mencari iklan dengan melakukan lobby ke instansi pemerintah. Dengan mendapatkan iklan, mereka bisa memperoleh komisi.

Dari informan pertama diperoleh data bahwa kondisi seperti itu terjadi setelah reformasi politik 1998. Media tumbuh sangat banyak tetapi tidak ada yang bisa bertahan, dan berguguran. Tentu saja wartawan-wartawan yang semula bekerja pada media tersebut tidak mau ikut mati bersama medianya. Ada yang patungan membuat situs online. Hanya dengan membayar Rp 1.000.000 mereka sudah bisa memiliki media online dan langsung menjadi karyawan di "perusahannya" sendiri. Modal yang murah itu dibayarkan untuk membeli domain (nama media online) dan sewa hosting (server yang menjadi rumah data).

Dari pengakuan Informan pertama, ada sisa sedikit uang untuk teknisi yang membuatkan template, merapikan situs dan hal-hal lain. Media online semacam ini tidak memiliki alamat atau kantor, badan hukum dan pengurus sebagai penanggung jawab sebagaimana ditentukan pasal 12, Undang-Undang Pers Nomor 40 Tahun 1999. Kantornya adalah tempat mereka melakukan liputan. Pengurusnya adalah mereka yang bergabung di media itu. Soal kesejahteraan sebagaimana diatur oleh Pasal 10 tentu tidak ada.

Gaji mereka berasal dari pendapatan tidak tetap yang didapat dari acara-acara jumpa pers yang memberikan uang transport atau pertemanan dengan politisi atau pejabat. Sehari-hari, mereka berangkat dari rumah seperti layaknya wartawan pada umumnya: meliput berbagai kegiatan, mengikuti pres gathering, sosialisasi undang-undang atau sosialisasi empat pilar ke berbagai daerah. Kementerian atau instansi di mana mereka meliput tidak pernah mempersoalkan keberadaannya dan tetap mengakui mereka. Setiap ada kegiatan yang melibatkan wartawan, banyak wartawan abal abal hadir di sana dan berstatus seperti wartawan sesungguhnya.

Informan pertama adalah pensiunan wartawan karena usia. Tidak banyak wartawan yang pensiun dan tinggal di rumah. Umumnya mereka mendirikan media online. Dari cara berpakaian terlihat paling rapi diantara informan lain. Karena berada di lembaga terhormat, penampilan mereka terlihat sopan dengan kemeja dan celana bahan. Di tempat itu juga banyak wartawan yang sudah pensiun, medianya bubar atau PHK, tetapi tetap menjalankan aktivitas dengan media baru. Sebagai anggota komunitas di satu unit (komunitas) wartawan, haknya sama: ikut sosialisasi, gathering, dapat THR dan lainnya (Iskandar, 2015).

Dengan pengalaman dan senioritas sebagai wartawan, informan pertama memiliki banyak kenalan para pejabat. Karakter informan yang keras juga mempengaruhi gayanya bila mengajukan pertanyaan ke narasumber atau pejabat saat jumpa pers, sangat kritis, terkadang berkesan menghakimi, membuat telinga merah. Bahkan dalam satu acara jumpa pers yang dihadiri Presiden Soesilo Bambang Yudhoyono (SBY) dan Wapres Jusuf Kalla, informan ini berani menginterupsi presiden, bertanya tentang hal substansial, kenaikan harga BBM. Jusuf Kalla yang diakuinya kenal dengannya saat itu hanya geleng-geleng 
kepala.

Beberapa wartawan memujinya saat ia bertanya. Saat itu menjelang pukul 24.00 , di mana media cetak menjelang deadline (batas waktu berita terakhir harus dilaporkan ke kantor dan dicetak). Bahkan saat itu banyak media cetak yang sudah tidak bisa menunggu lagi karena harus naik cetak. Apalagi dari pernyataan Presiden SBY sejak awal belum ada materi yang menarik sehingga informan ini berinisiatif menanyakan hal yang kemungkinan jawabannya akan menjadi berita. Benar saja, dari pertanyaan informan itu, dijawab oleh SBY dan itulah satu-satunya materi jumpa pers yang bernilai berita.

Dalam keseharian informan ini bersahaja, naik angkutan umum kemanapun pergi. Makan di warung belakang gedung atau di basemant yang terdapat warung makan para sopir. Santun dalam bertata krama dan tidak keras seperti saat bertanya kepada narasumber. Karakter kerasnya tidak terlihat saat bersama-sama dengan wartawan. Begitu juga dengan keluarga, dia seorang bapak yang halus. Hal ini diketahui pada saat dia menghubungi anaknya yang masih sekolah dengan bahasa yang berbeda dengan ketika bertanya kepada narasumber berita.

Informan satu ini dulu bekerja di koran sore tapi kini tutup. Saat ini tidak jelas dimana informan ini bekerja, tetapi komunitas masih mengakuinya sebagai wartawan. Beberapa kali terlihat ia menulis berita, atau lapor menggunakan HP. Pada waktu koran sore masih hidup, ia sibuk mencari dan melaporkan berita yang didapatnya ke kantor redaksi. Semua wartawan tahu dia memiliki link khusus dengan pasangan pejabat tinggi negara. Inilah satu-satunya wartawan yang pernah menumpang mobil pejabat dengan plat nomor RI dan turun di jalan untuk melanjutkan perjalanan dengan angkutan umum. Dia mengaku di halte tempat dia berhenti, orang kaget ketika mobil dinas itu berhenti. Termasuk ketika berbaur diantara para penunggu bis, mereka sempat melihat ada yang aneh.

Informan ini mengaku pernah diberi sebuah mobil dari pejabat itu, tapi karena untuk mencukupi kebutuhan sehari-hari maka mobil tersebut dijual. Kini dia bekerja di media yang tidak banyak dikenal masyarakat. Dia butuh bendera eksistensi sebagai wartawan, sehingga tetap memiliki privilege sebagai wartawan: berhak ikut press gathering tiga bulan sekali, sosialisasi produk regulasi, kunjungan pejabat dan lain-lain. Inilah frontstage seorang wartawan. Setelah pulang dari bertugas itulah backstage wartawan: kembali ke dunia nyata.

Informan kedua, sejak jadi wartawan mengaku bekerja di perusahaan media yang terbit di daerah. Tidak pernah jelas nama medianya, sehingga orang hanya tahu ia bekerja di koran terbitan daerah. Dengan kondisi sekarang, bisa jadi koran daerah itu sudah tidak ada dan tidak pernah ada juga yang menanyakan dia bekerja dimana. Orang hanya tahu setiap hari dia ada pressroom dan dia tetap dianggap sebagai wartawan. Biasanya wartawan-wartawan yang ada di ruang khusus reporter itu membuat berita dengan laptop pribadi atau fasilitas komputer yang ada di ruangan itu. Tapi informan ini tidak pernah membuat berita. Namun, acara apapun yang diadakan, dia pasti ikut. Kalau tidak ada acara, dia hanya duduk-duduk di ruang wartawan bersama wartawan lain.

Di ruangan itu, wartawan yang datang tidak perlu membawa perangkat kerja karena di ruang pressroom disediakan personal komputer lengkap dengan jaringan internet. Wartawan yang datang dan tidak jelas medianya juga banyak jumlahnya. Tapi karena mereka sudah lama berada di tempat itu dan mengaku sebagai wartawan, tidak ada yang mengusiknya. Di institusi itu tidak ada verifikasi mengenai siapa dan wartawan dari media apa mereka berasal.

Ada juga yang berasal dari media terkenal. Tapi ketika kantor menugaskan dia untuk pindah liputan ke tempat lain, dia menolak. Dia lebih memilih keluar dari media yang mempekerjakannya daripada harus pindah liputan. Ini menandakan bahwa tempat ini, 
tidak hanya sebagai episentrum politik tanah air tetapi juga menjadi episentrum berita dan rejeki bagi banyak orang termasuk wartawan. Meskipun begitu orang melihatnya sebagai wartawan yang bekerja di tempat terhormat.

Informan ketiga adalah seorang fotografer yang semula bekerja di perusahaan pers terverifikasi Dewan Pers. Dia terkena rasionalisasi dan harus keluar dari tempatnya bekerja yang sudah puluhan tahun. Pendidikan informan ini tidak memadai untuk ukuran reporter atau fotografer saat ini. Ia hanya lulus Sekolah Dasar. Dulu, di kantor tempat dia bekerja pertama, tugasnya adalah office boy. Ketika reformasi 1998, perusahaan pers tempatnya bekerja itu kekurangan wartawan, sehingga dia diminta mengambil foto-foto kerusuhan 1998. Dari peristiwa itu, kantor tempatnya bekerja mengubah posisinya dari office boy menjadi fotografer.

Dari performance komunikasi, informan ini kurang lancar dalam sistematika dan mendeskripsikan aktifitas pekerjaannya. Beberapa kali menjawab pertanyaan, sulit dipahami apa saja tugasnya saat bekerja di kantor lama dan pekerjaan sekarang. Ternyata faktor pendidikan mempunyai pengaruh dalam kinerja wartawan meskipun dalam karya fotonya tidak selalu demikian. Bisa jadi karena sudah terbiasa menggunakan peralatan foto dia tahu cara-cara/teknik foto.

Dia mengaku tidak membawa nama kantor lamanya setelah terjadi pengurangan karyawan bersamaan dengan merebaknya virus Covid-19. Namun di tetap "gagah" seperti wartawan lainnya berada di front stage. Informan ini membuat situs berita online bersama beberapa wartawan dan fotografer lain. Dengan begitu meskipun sudah keluar dari perusahaan lama, sampai saat ini tidak pernah meninggalkan gedung tempat ia meliput selama ini. Komunitas wartawan maupun fotografer di sana juga tidak ada yang mempermasalahkannya. Mereka semua memahami kondisi masing-masing dengan prinsip masing-masing.

Jumlah wartawan di tempat itu dari waktu ke waktu tidak pernah berkurang dan cenderung bertambah. Apalagi fasilitasnya sangat nyawan, jaringan Wi-fi free, televisi layar lebar, komputer PC di beberapa meja, ruang pertemuan, mushola dan lainnya. Para pejabat, menteri, politisi dari berbagai instansi silih berganti datang memberikan keterangan pers. Rata-rata setiap tiga bulan sekali dalam rombongan besar mereka melakukan kunjungan bersama pejabat dan seluruh wartawan ke Bali, Lombok, Medan, Makassar dan kota-kota di Indonesia dalam rangka sosialisasi berbagai program.

Para informan menunjukkan foto-foto dokumentasi ke beberapa destinasti wisata yang mereka kunjungi. Begitu juga perjalanan mereka baik dengan kereta kelas eksekutif maupun pesawat udara. Beberapa diantaranya ada juga foto dokumentasi, mereka sedang berenang di pantai atau di kolam renang hotel. Foto-foto dokumentasi lain tampak dengan pejabat instansi maupun pejabat daerah.

Apa yang diterima dan dikemukakan para wartawan pada awal pembahasan ini adalah front stage kehidupan wartawan. Bagian depan dari kehidupan wartawan saat ini yang terlihat indah. Di tampak depan secara jelas disaksikan oleh audience. Apa yang ditampilkan adalah sosok yang mewakili kesempurnaan hidup. Serba enak, mewah, elit, bersenang-senang dan mendapatkan uang saku berdasarkan ketentuan pemerintah meskipun mereka bukan bagian dari pemerintah.

Berdasarkan sejumlah aktifitas yang dirangkai dari informan, maka dapat dirinci dalam beberapa sudut bagian yang dapat dikemukakan yaitu: (1) tempat mereka beraktifitas sebagai wartawan adalah instansi di mana sehari-harinya terdapat fasilitas yang telah disiapkan, berupa fasilitas penunjang kerja seperti komputer, tv, $W i-f i$, meja kursi, dan lain-lain; (2) tempat mereka mengadakan sosialisasi yaitu berbagai daerah dimana mereka bisa menikmati kemewahan atas tanggungan negara dan mendapat uang saku; (3) perjalanan yang nyaman sepanjang menuju objek yang telah ditentukan. 
Wartawan tinggal duduk sampai ke tempat tujuan sambil menikmati hiburan, dan lainlain; (4) rumah, tempat mereka merasakan dunia yang sesungguhnya yang tidak memerankan orang lain atau memainkan drama tetapi keadaan yang harus dijalani secara normal. Mengurus kebutuhan, makan menggunakan ukuran yang dimilikinya, bukan ukuran pemain sandiwara.

Dalam teori dramaturgi ada back stage atau panggung belakang. Lingkungan keluarga, lingkungan tetangga adalah bagian dari panggung lain para wartawan. Mereka akan kembali ke rutinitas sebagai orang biasa dengan berbagai keterbatasan. Mereka menikmati gaji dari kantornya yang kebanyakan tidak sebesar pekerja profesional. Mereka, sejatinya tidak banyak tahu tentang hal-hal tertentu secara mendalam. Tentang politik, ekonomi, budaya dan lainnya. Para wartawan hanya tahu luarnya, itupun tidak banyak tetapi aktual sehingga seakan-akan menutupi kekurangan atas ketidaktahuan terhadap satu masalah secara mendalam.

Mereka kembali ke rumah tetap dengan naik angkutan umum, naik motor, memikirkan bensinnya, tolnya, nebeng teman atau ada beberapa diantaranya yang membawa mobil sederhana. Sampai di rumah pun mereka menempati rumah yang tidak sebagus hotel ketika berada di panggung depan. Tidak jarang mereka menempati rumah kontrakan, setengah permanen. Itupun semua dibiayai sendiri, listrik, air, wi-fi. Makanan yang dimakan pun diukur dengan pendapatan yang diperoleh sehari-hari. Sungguh berbeda dengan front stage: mereka tidak tahu harganya bahkan tidak tahu namanya. Yang mereka tahu hanya menghabiskan dan menikmati kenyamanan.

Di back stage mereka harus benar-benar berperan sebagai dirinya sendiri dengan ukuran yang dimiliki, tidak bisa meminta lebih tetapi harus dicukupkan. Mereka juga harus memperlakukan dan diperlakukan secara sejajar sebagai keluarga. Bukan dilayani seperti tamu hotel, bukan disiapkan pramugari seperti saat menumpang pesawat atau menanyakan kebutuhan-kebutuhan penunjang liputan kepada staf pendamping. Semua disiapkan sendiri termasuk mengadakan sendiri dengan cara dan kemampuannya sendiri.

Sebagai warga di lingkungan suatu kawasan tertentu dia juga harus menyesuaikan dengan kebiasaan dan budaya yang berlaku, tidak bisa memilih-milih waktu misalnya untuk ronda, bersosialisasi, dan lain-lain. Semua ini adalah bentuk dari perubahan sosial yang tidak bisa dihindari. Semua aspek dan perilaku manusia disebabkan langsung oleh pengaruh lingkungan yang hidup dan berkembang. Sedangkan bentuk budaya akan ditentukan oleh lingkungan geografis, iklim dan sumber daya alam. Kreasi lingkungan itu akan membentuk manusia dengan berbagai karakter (Mudjahirin Tohir, 2018).

Ketika membahas soal dramaturgi muncul panggung ketiga yang bukan panggung depan atau panggung belakang. Yaitu daerah luar yang disebut bidang residual (Ritzer \& Goodman, 2007). Daerah ini berada di luar pertunjukan aktor, yaitu bukan panggung depan maupun panggung belakang. Di panggung depan informan menunjukkan betapa berbagai nilai positif dan kelebihan yang dimiliki seorang wartawan, tapi pada panggung belakang saat dia tidak sedang berakting, ia melakukan hal yang terkait dengan hidupnya, keluarga dan lainnya. Audien teman sesama wartawan, staf dimana dia mencari berita tahu dan memahami apa yang mereka cari di tempat itu. Audien sesungguhnya tahu apa yang mereka cari tanpa harus bertanya. Maka reputasi aktor akan rusak apabila ia masuk ke panggung belakang.

\section{KESIMPULAN}

Berdasarkan hasil pembahasan, dapat ditarik kesimpulan wartawan sering berada di panggung depan (front stage) yang berkilau sehingga kalau tidak bisa kembali ke panggung belakang (back stage), maka akan terus bermain peran. Padahal profesi wartawan sejatinya adalah pekerjaan idealis yang membawa kepentingan orang banyak. 
Menjadi wartawan tidak akan membuat dia menjadi kaya, namun ada kesenangan kecil yang tidak bisa diukur dengan uang. Artinya satu pihak menuntut idealisme, sedangkan yang lainnya adalah ketidakmampuan mempertahankan idealisme. Secara jelas maka dua pernyataan itu pada dasarnya adalah cerminan dari dramaturgi yang dimainkan oleh para wartawan.

Front stage yang diperankan pada profesi wartawan yang serba tahu dan merasa paling penting terjadi di tempat peliputan atau pencarian berita, tempat mereka mengikuti kegiatan-kegiatan lembaga, press gathering, kegiatan sosialisasi dan kunjungan daerah

Kesenangan kecil dan menikmati apa yang diperolehnya sebagai wartawan dengan penghasilan sedikit tapi harus cukup adalah bagian dari panggung belakang (back stage) bersama keluarganya. Tetap menjadi keluarga terhormat dan dihormati keluarganya sebagai pekerja profesional.

Malah ada bagian dunia luar yang bukan front stage atau back stage tetapi menjadi saksi dari pertunjukan yang berlangsung, yaitu daerah luar yang disebut bidang residual. Di bagian ini terjadi kerjasama antara audien dengan informan karena ada sebuah kerahasiaan yang dijaga tentang perilaku informan.

\section{Ucapan Terima Kasih}

Peneliti mengucapkan terima kasih kepada semua pihak yang membantu penelitian ini, termasuk kepada para informan yang telah memberikan masukan, ide, maupun ceritaceritanya.

\section{Dafar Pustaka}

Astraatmadja, A. (1998), Reformasi Media Massa, Jakarta: Aliansi Jurnalis Independen (AJI),

Batubara, S.. (2008), Menegakkan Kemerdekaan Pers, Kumpulan Makalah 1999-2007, Jakarta: Dewan Pers.

Denzin, K, N. \& Lincoln, S, Yvonna. (2009). Handbook of Qualitative Research. Yogyakarta: Pustaka Pelajar.

Goffman, E. (1959). The Presentation of Self in Everyday Life. New York: Doubleday Anchor Garden City.

Iskandar, S.B. (2015), Keruntuhan Jurnalisme, Jakarta: Lentera Ilmu Cendekia

Kivisto, P. \& Pittman, D. (2007). Goffman's dramaturgical sociology: Personal sales and service in a commodified world dalam P. Kivisto (Ed.), Illuminating social life: classical and contemporary theory, 4th ed (h.271-290). Thousand Oaks: Pine Forge Press.

Littlejohn, S.W \& Karen A. Foss. (2018). Teori Komunikasi, (Theories of Human Communication), Jakarta: Salemba Humanika

Manan, B. (2014). Politik Publik Pers. Jakarta: Dewan Pers

Mulyana, D. (2017). Ilmu Komunikasi Suatu Pengantar. Bandung: PT. Remaja Rosdakarya.

Oetama, J. (2001), Pers Indonesia, Berkomunikasi dalam Masyarakat Tidak Tulus, Jakarta: Kompas.

Pudjomartono, S. (1998), Reformasi Media Massa, Jakarta: Aliansi Jurnalis Independen.

Rasyid, A. (2017). Dampak Negatif Kebebasan Pers di Kota Medan, Jurnal Ilmu Komunikasi dan Kajian Islam, 4(2).

Ritzer, G. \& Goodman, J, Douglas. (2007). Teori Sosiologi Modern. Jakarta: Kencana Prenada Media Group.

Sumadiria, H. (2017), Jurnalistik Indonesia, Menulis Berita dan Feature, Bandung: Sembiosa Rekatama Media. 
Sutrisno, E. (1998), Reformasi Media Massa, Jakarta: Aliansi Jurnalis Independen.

Tapsell, R. (2019), Kuasa Media di Indonesia, Kaum Oligarki, Warga, dan Revolusi Digital. Jakarta: Margin Kiri.

Tohir, M. (2018). Materi Mata Kuliah Filsafat Ilmu. Semarang: Universitas Diponegoro Semarang. 